\title{
Koncepcja „nieuświadomionego Boga” — rozważania po Holocauście Victora Frankla
}

\begin{abstract}
Ten, kto pozostał żywy na Syjonie i który się ostał w Jeruzalem, każdy będzie nazwany świętym i wpisany do [Księgi] Życia w Jeruzalem.
\end{abstract}

Iz. 4,3

Victor E. Frankl (1905-1997) był wybitnym psychiatrą i neurologiem, twórcą trzeciej szkoły wiedeńskiej psychiatrii, określanej mianem logoterapii i analizy egzystencjalnej. Pierwszą szkołę psychiatrii wiedeńskiej założył Sigmund Freud, twórca psychoanalizy; twórcą drugiej szkoły — nazywanej w literaturze psychologią indywidualną — był Alfred Adler, uczeń i współpracownik Freuda; natomiast założycielem trzeciej szkoły jest Frankl, uczeń Adlera, który porzucił intelektualnie swojego mistrza, chociaż sporo od niego zaczerpnął, zarówno z teorii, jak i praktyki ${ }^{1}$. Wymienione postacie łączyła więź osobista (wszyscy się osobiście poznali i spotykali się, do pewnego czasu Freuda i Adlera łączyła zażyłość towarzyska i zawodowa) i intelektualna (wspólne inspiracje psychoanalizą i filozofią egzystencjalną), mimo wyraźnie zaznaczanych różnic ${ }^{2}$. Oczywiście, w najbliższym związku intelektualnym i towarzyskim pozostawali Freud i Adler, Frankl był dopiero dobrze zapowiadającym się klinicystą, który w pełni rozwinął się zawodowo i intelektualne po II wojnie światowej, gdy obaj wybitni psychiatrzy już nie żyli.

${ }^{1}$ Od Adlera Frankl zaczerpnął zwrócenie uwagi na środowisko społeczne pacjenta i jego wychowanie dla rozwoju psychicznego jednostki oraz na znaczenie sensu życia w leczeniu klinicznym. Ponadto Frankl niewątpliwie inspirował się dokonaniami Adlera, zakładając sieć poradni klinicznych dla młodzieży.

2 Według K. Horney ,zasadniczym składnikiem psychoanalizy są pewne podstawowe kierunki myślenia dotyczące roli procesów nieświadomych i sposobów ich wyrażania oraz specyficzna forma terapii doprowadzającej do uświadomienia sobie tych procesów" (eadem, Neurotyczna osobowość naszych czasów, Poznań 1999, s. 14). 
Frankl odczytał Freudowską psychoanalizę, szczególnie jej drugą wersję ${ }^{3}$, poprzez koncepcję psychologii indywidualnej Adlera i sformułował koncepcję logoterapii i analizy egzystencjalnej ${ }^{4}$. Podobnie jak wymienieni uczeni, Frankl miał aspirację do podejmowania problematyki filozoficznej ${ }^{5}$; jego rozważania koncentrowały się wokół traumatycznych doświadczeń granicznych człowieka (samobójstwo, cierpienie, Holocaust), na które spoglądał z szerokiej perspektywy filozofii egzystencjalnej (A. Schopenhauer, F. Nietzsche, M. Heidegger, ale i J.P. Sartre, z którym był w sporze) i fenomenologii E. Husserla i M. Schelera. Szczególnie traumatyczne wydarzenia związane z Zagładą stają się dla niego przełomem, dostrzegalnym $\mathrm{w}$ jego filozoficznych rozważaniach ${ }^{6}$, w mniejszym stopniu w praktyce klinicznej ${ }^{7}$.

Artykuł podejmuje zagadnienia Holocaustu i kondycji współczesnego człowieka „po Auschwitz”, na które Frankl spogląda z perspektywy lekarza, ale i filozofa. Odwołując się koncepcji hermeneutyki, dokonuję krytycznej analizy prac Frankla ${ }^{8}$. Podejmuję w artykule tylko zagadnienia filozofii społecznej (w rozumieniu Sokratejskim), jednocześnie będąc politologiem, spoglądam na wspomniane zagadnienia z perspektywy historyczno-politycznej.

Przedmiotem refleksji jest koncepcja „nieuświadomionego Boga”, będąca odpowiedzią Frankla na skargi teologiczno-filozoficzne Hansa Jonasa, a także innych żydowskich teologów (takich jak np. M. Buber) na ,śmierć Boga" w Auschwitz'; przy czym rozważania teologów żydowskich nie są przedmiotem analizy ${ }^{10}$. Dostrzegam w pracy Frankla polemikę z humanistyczną neopsychoanalizą Ericha Fromma, bez przywoływania autora i jego poglądów, polemikę nie wprost. Frank1 swoją krytykę kieruje pod adresem egzystencjalizmu Sartre'owskiego, odwołującego się do tradycji klasycznego humanizmu,

3 E. Fromm, Anatomia ludzkiej destruktywności, Poznań 1999. Istotą drugiego przełomu dokonanego po 1920 r. jest odrzucenie teorii libido i sformułowanie przez Freuda koncepcji popędu śmierci i życia (Thanatos i Eros).

${ }^{4}$ V.E. Frank1, Homo patiens, Warszawa 1998; idem, Człowiek - wartość - sens. Studia z psychologii egzystencjalnej. Logoterapia i nooteoria. Logoterapia i nooterapia, red. K. Popielski, Lublin 1996, szczególnie teksty K. Popielskiego w cytowanym zbiorze. Zagadnienia kliniczne nie są przedmiotem analizy.

5 Już pierwsze prace Frankla zdradzają zainteresowania problematyką filozoficzną: On the Psychology of philisophical Thought (o A. Schonephauerze z 1923 r.), Psychoterapy and Weltansachaaung (pytanie o relację psychiatrii i filozofii z 1925 r.), www.viktorfrankl.org/e/lifeandwork (dostęp: 25.10.2015).

${ }^{6}$ M. Nieć, Filozofia polityki Victora Frankla w cieniu Holocaustu. Refleksje politologa, „Roczniki Nauk Społecznych” 2014, nr 3, s. 141-169.

${ }^{7}$ K. Popielski podkreśla powstanie koncepcji klinicznej Frankla już przed II wojną światową, zob. przypis 24 .

8 Teorie i metody w naukach politycznych, red. D. Marsch, G. Stoker, Kraków 2006.

9 H. Jonas, Idea Boga po Auschwitz, Kraków 2003. Wspomniana praca jest co prawda z lat 80. XX w., ale Jonas formułuje powyższe idee tuż po II wojnie światowej.

${ }^{10}$ Teologia i filozofia żydowska wobec Holocaustu, red. P. Śpiewak, Gdańsk 2013. 
podobnie jak neopsychoanaliza Frommowska. Przy tym Fromm jest czołowym przedstawicielem szkoły frankfurckiej, łączącej psychoanalizę z Marksowską refleksją $^{11}$, podczas gdy Sartre jest filozofem sięgającym do spuścizny francuskiego racjonalizmu nowożytnego i fenomenologii Husserla, a także do egzystencjalizmu. W 1946 r. powstaje praca Sartre'a pod wymownym tytułem Egzystencjalizm jako humanizm ${ }^{12}$, która staje się przedmiotem polemiki, o tyle zasadnej, że Sartre'owski egzystencjalizm zostaje we wspomnianej pracy poddany swoistej auto-wulgaryzacji ${ }^{13}$. W Franklowskiej krytyce egzystencjalizmu Sartre'a możemy odnaleźć polemikę z humanistyczną neopsychoanalizą, ostrze krytyki kierowane jest także pod adresem tradycji humanistycznej mającej swoje korzenie w twórczości Protagorasa z Abdery, ale również negatywne oceny padają pod adresem egzystencjalnego nihilizmu. Przy czym warto zaznaczyć, że określenie nihilizm egzystencjalny Frankl odnosi do francuskiej tradycji egzystencjalnej.

W 1947 r. Fromm opublikował po angielsku pracę Niech się stanie czlowiek. Z psychologii etyki (Man for Himself. An Inquiry into the Pscychology of Ethics) ${ }^{14}$, będąc próbą zmierzenia się z kryzysem kondycji ludzkiej „po Auschwitz”. Praca ta podsumowała pierwszy okres jego twórczości i rozważań nad totalitaryzmem, zapoczątkowany Ucieczka od wolnośsi ${ }^{15}$. Jak wyjaśnia Fromm:

[Man for Himself] stanowi pod wieloma względami kontynuację mojej wcześniejszej pracy Ucieczka od wolności, w której próbowałem poddać analizie zjawisko ucieczki współczesnego człowieka od samego siebie i od wolności. W niniejszej pracy omawiam etyczną problematykę norm i wartości prowadzących do realizacji natury człowieka i jego potencjalnej mocy ${ }^{16}$.

W tym samym czasie Frankl podejmuje bardzo zbliżoną problematykę, koncentrując swoje rozważania na kwestii sumienia, odpowiedzialności człowieka za czyny „w Auschwitz”. Przy tym perspektywa ofiary Holocaustu, więźnia obozów koncentracyjnych różni się zasadniczo od analityki nieświadomości, emigranta, uciekającego przed prześladowaniami, prawdopodobnie nawet przed śmiercią. Właśnie w odmienności tragicznego losu opisywanego przez obydwu psychoanalityków postrzegam inne przesłania - w przypadku Fromma mamy podtrzymanie wiary w człowieka, formułowane w zaciszu zwycięskiej demokracji północnoamerykańskiej ${ }^{17}$, podczas gdy w przypadku Frankla następuje zwątpienie

11 M. Chałubiński, Fromm, Warszawa 1993; idem, A. Szahaj, Teoria krytyczna szkoty frankfurckiej. Wprowadzenie, Warszawa 2008.

12 J.P. Sartre, Problem bytu i nicości. Egzystencjalizm jest humanizmem, Warszawa 2001.

13 M. Kowalska, Wstep, [w:] J.P. Sartre, op. cit., s. 5.

14 E. Fromm, Niech się stanie człowiek. Z psychologii etyki, Warszawa-Wrocław 1994.

15 E. Fromm, Ucieczka od wolności, Warszawa 1970.

16 E. Fromm, Niech się stanie czlowiek..., s. 7.

17 Fromm sformułuje bardziej pogłębioną wizję zbrodniczej natury człowieka w pracy Anatomia ludzkiej destrukcyjności z 1973 r., już po konflikcie koreańskim i wietnamskim. W analizach powrócił do postaci Stalina, Hitlera, Himmlera, dostrzegając w ich losie wątki uniwersalne. 
w człowieka, głośno wyrażone z wiedeńskiej strefy okupacyjnej, pogrążonej w chaosie postautorytarnego państwa krematoriów. Gdy Fromm spogląda przez wiwatujące thumy zwycięzców na Times Square, Frankl przygląda się przegranym sąsiadom-oprawcom, Austriakom uwiedzionym przez hitleryzm — prawdopodobnie ma $\mathrm{w}$ pamięci oszalałe $\mathrm{z}$ radości thumy wiedeńczyków wiwatujące na cześć Adolfa Hitlera w marcu 1938 r. Owo złożenie euforii Austriaków z żywym wspomnieniem oprawcy, nie tylko z obozu, lecz także z ulic brunatnego Wiednia, Innsbrucku czy Grazu prawdopodobnie niosło silny ładunek emocjonalny w ocenach postępowania rodaków. Ponadto w 1938 r. ujawnił się wyraźny konflikt dwóch wartości w byłej monarchii Habsburgów: odrodzenia mocarstwowości wspólnoty państwowej (narodowej) za cenę „ucieczki od człowieczeństwa”18 / porzucenia moralności. Austriaccy zdecydowali się na połączenie z Trzecią Rzeszą, mając świadomość tragicznych skutków, jakie niósł anschluss dla nie-niemieckiego społeczeństwa. Frankl we wspomnieniach obozowych ...mimo wszystko, życiu powiedziatem tak. Psychologa doświadczenie obozu koncentracyjnego ${ }^{19}$ przypomina, jak zaraz po wyzwoleniu pobiegł do swoich przyjaciół ze szkoły, by zadać im pytanie, dlaczego dopuścili do tak potwornych zbrodni. Uzyskał odpowiedź jak najbardziej prozaiczną — „baliśmy się”. Oto strach staje się silniejszy niż elementarne poczucie przyzwoitości, człowieczeństwa. Frankl traci zatem wiarę w człowieka - nie na tyle, by go porzucić, ale by mu już nie ufać. Sytuuje współczesnego człowieka między „spętanym aniołem” a „szlachetną bestią"20.

Paradoksalnie (a może nie — wszak to diagnoza psychoanalityka) Ucieczka od wolności mieści się we Franklowskim rozumieniu natury ludzkiej, natomiast druga praca Fromma, jego wizja przezwyciężenia ucieczki, jest dla Frankla nie do przyjęcia z powodów ideologicznych, innej wizji zabezpieczenia świata „przed Auschwitz". Nie mogę jednoznacznie stwierdzić, czy Frankl znał obydwie prace Fromma, gdy pisał Nieuświadomionego Boga - Ucieczka od wolności została bowiem opublikowana w 1942 r., natomiast Niech się stanie człowiek w 1947 r.; w tym czasie Frankl kończył już swój doktorat. Znał na pewno pracę Sartre'a Egzystencjalizm jest humanizmem, która wywołała jego oburzenie i polemikę. Przedstawmy zatem główne myśli Frankla; prace Fromma i Sartre'a nie są przedmiotem analizy, traktuję je jako tło.

Już w okresie międzywojennym, od połowy lat 20. XX w. Frankl interesuje się samobójcami, osobami, które w desperackim geście odrzucają życie jako wartość i sens. W okresie kryzysu ekonomicznego i politycznego, szczególnie $\mathrm{w}$ republice weimarskiej, ale także w republice austriackiej dochodzi do zwiększonej liczby samobójstw. W miarę narastania kryzysu nasilają się nie tylko akty

18 Frankl nie używa powyższej frazy, ale wynika ona z jego antropologii i biografii.

19 Praca ukazała się pod zmienionym tytułem angielskim Man's Search for Meaning (Człowiek $w$ poszukiwaniu sensu, Warszawa 2009).

20 V.E. Frankl, Bóg ukryty. W poszukiwaniu ostatecznego sensu, Warszawa 2012, s. 92. 
suicydalne, ale także zachowania agresywne i inne aspołeczne działania ${ }^{21}$. Badania ówczesnych socjologów i psychologów społecznych dowodzą pojawiania się syndromu faszystowskiego, ujawnia się też akceptacja dla wykluczeń społecznych i postaw autorytarnych ${ }^{22}$.

Powyższe problemy stają się początkowo przedmiotem zainteresowania lekarskiego, a następnie filozoficznego „młodego” Frankla ${ }^{23}$. Tuż przed wybuchem II wojny światowej formułuje on koncepcję logoterapii i analizy egzystencjalnej ${ }^{24}$. Pierwszą koncepcję możemy przypisać do jego zainteresowań medycznych (neurologii, psychiatrii i psychologii klinicznej), natomiast drugą — do refleksji społecznej w rozumieniu klasycznej nauki, szczególnie do antropologii filozoficznej i kulturowej (E. Husserl, M. Scheler ${ }^{25}$ ). Problematyce logoterapii poświęcono bardzo wiele publikacjii ${ }^{26}$, co zwalnia z jej prezentacji, natomiast podejmuję się zasygnalizowania kilku zagadnień, które możemy umieścić w filozofii polityki. One i tylko one są przedmiotem refleksji naukowej.

Zasadniczym rysem Franklowskiej antropologii społecznej jest kształtowanie jej na tle własnej biografii ${ }^{27}$. Frankl jest Austriakiem wyznania mojżeszowego (w nomenklaturze prawicowo-rasistowskiej - Żydem), co z definicji naznacza cierpieniem jego życie w Trzeciej Rzeszy; przeżył getto w Teresinie, obozy w Auschwitz (więzień o numerze 119 104) i Dachau. Jest wybitnym intelektualistą niemieckim, świetnie obeznanym z kulturą niemiecką, ale także patriotą austriackim. Po zakończeniu wojny powrócił do Wiednia ${ }^{28}$.

Nie prezentując jego biografii, bardzo interesującej i literackiej, szczególnie we fragmentach odnoszących się do jego życia uczuciowego ${ }^{29}$, poświęćmy uwa-

${ }^{21}$ E. Durkheim, Samobójstwo. Studium z socjologii, Warszawa 2006; A. Sułka, Przedmowa, [w:] ibidem, s. 13-46, tu aktualizacja badań nad samobójstwami.

22 Odwołuję się do badań głównie ośrodka frankfurckiego (szkoły frankfurckiej). Częéś wyników badań jest publikowana albo na emigracji, albo po wojnie; T. Adorno, Osobowość autorytarna, Warszawa 2010; także K. Horney, op. cit.

23 Biografię intelektualną Frankla dzieli się na cztery okresy. Sformułowanie „młody” Frankl odnoszę do czasu sprzed II wojny światowej. Zob. J.T. Michalski, Sens życia a pedagogika. Impulsy myśli Victora E. Frankla, Toruń 2011, s. 24-42.

24 W 1939 r. powstaje praca Philosophy and Psychotherapy.on the Foundation of an Existential Analysis, w której Frankl formułuje koncepcję logoterapii/psychoterapii i analizy egzystencjalnej/filozofii życia.

25 Szczególnie praca M. Schelera, Der Formalismus in der Ethik und die materiale Wertethik wywarła wpływ na koncepcje etyczne Frankla. Zob. fragment wspomnianej pracy M. Schelera, Istota osoby moralnej, [w:] Filozofia i socjologia XX w., cz. 2, Warszawa 1965, s. 354-370.

${ }^{26}$ Choćby cytowane prace K. Popielskiego, J.T. Michalski, ale także liczne teksty M. Wolickiego.

27 Metoda biograficzna w socjologii, red. J. Włodarek, M. Ziółkowski, Warszawa-Poznań 1990.

28 Tło historyczno-intelektualne jego koncepcji przedstawiłem w artykule Cień Holokaustu w twórczości Victora Frankla i Jerzego Kosińskiego, [w:] Rodzina - wychowanie w cieniu Holokaustu, red. A. Łacina-Łanowski, W. Stankowski, A. Świerczek, Oświęcim 2017, s. 67-81.

29 V.E. Frankl, ...mimo wszystko, życiu powiedziałem tak...; szczególnie fragmenty wspomnień dotyczące jego pierwszej żony — Tilly Grosser. 
gę jego koncepcji filozoficznej formułowanej tuż po II wojnie światowej, będącej spojrzeniem na Holocaust i totalitaryzm „na żywo" ${ }^{30}$. Przedmiotem analizy czynię koncepcję „nieuświadomionego Boga”, która jest podstawą jego obronionej dysertacji doktorskiej z filozofii w 1948 r. Praca zatytułowana Nieuświadomiony Bóg ukazała się drukiem w Austrii w 1948 r., natomiast w wersji anglojęzycznej w 1975 r. Dopiero po śmierci Frankla, w 2011 r. ukazała się wersja rozszerzona pracy, pod zmienionym tytułem: Bóg ukryty. W poszukiwaniu ostatecznego sensu ${ }^{31}$.

Zmiana tytułu — podkreślmy, że w pracach kierowanych do anglojęzycznego czytelnika - jest tylko pozornie niewielką różnicą; przez zmianę tytułu Frankl dokonuje zmiany wymowy dzieła. Już nie ,przypadek niemiecki”, eufemistycznie ujmując, jest sednem analizy, lecz uniwersalne problemy ludzkości, na które spogląda $\mathrm{z}$ dystansu ${ }^{32}$. Frankl zdaje się przyjmować, za niemieckimi i austriackimi politykami, optymistyczną tezę, formułowaną przynajmniej na poziomie ideologicznym od końca lat 50. XX w. o przezwyciężeniu skutków II wojny światowej. Niewątpliwie sukcesy gospodarcze i polityczne pierwszego pokolenia powojennego Niemców mogą skłaniać do tego typu poglądu ${ }^{33}$.

Po prawie 30 latach od sformułowania koncepcji „nieuświadomionego Boga” Frankl następująco ocenił jej aktualność:

Niemniej teza wyjściowa mojego odczytu zatytułowanego Nieuświadomiony Bóg wciąż pozostaje aktualna i możliwa do obrony. W głębi nieświadomości każdego człowieka tkwi bowiem głęboko zakorzenione poczucie religijności ${ }^{34}$.

Zagadnienie relacji religia-psychoterapia jest również przedmiotem arcydzieła Franklowskiej antropologii Człowiek w poszukiwaniu sensu, a także Wola sensu i Człowiek wolny. Wyktady metakliniczne oraz Homo Patiens. Próba wyjaśnienia sensu cierpienia, podsumowująca pierwsze 5-lecie powojennej refleksji antropologicznej Frankla ${ }^{35}$. W ostatniej z wymienionych prac Frankl antycypuje nadchodzące zagrożenia dla ludzkości, słychać echo zbliżającej się „zimnej wojny"36, która zmieni jego ocenę historiozoficzną Holocaustu. Zagłada zostanie także wpisana w ciąg kolejnych tragicznych wydarzeń historycznych (Hiroszima, Wietnam), jak i obaw politycznych przed konfliktem nuklearnym (Korea, Kuba).

30 Wspomnienia obozowe, arcydzieło nauki i biografistyki Frankl napisał w ciągu dziewięciu dni 1945 r. Już we wspomnieniach pojawia się idea „nieuświadomionego Boga”.

31 Bardzo wiele fragmentów jest obszernymi powtórzeniami, pojawiły się dopowiedzenia i dodatkowy rozdział; Frankl nie dokonał rewizji wcześniejszej koncepcji.

32 Powyższa uwaga odnosi się także do innych prac antropologicznych z okresu 1945-1950, które ukazały się po kilku latach w Stanach Zjednoczonych. W zależności od kontekstu przywołuję niemiecką bądź angielską wersję.

33 Jako najważniejsze wydarzenia możemy wymienić: integrację RFN w ramach EWG i NATO oraz odzyskanie niepodległości przez Austrię w 1955 r.

34 V.E. Frankl, Bóg ukryty..., s. 24. Tak sformułowana teza nie jest zbyt oryginalna, jest głoszona w Biblii, a także pojawia się w filozofii klasycznej, np. u pitagorejczyków.

35 W latach 1945-1950 Frankl formułuje zasadnicze tezy koncepcji antropologicznej.

36 Odnoszę się do jego reakcji na próby z nową bronią atomową — bronią termojądrową. 
U Frankla, podobnie jak u Fromma, ale też u innych żydowskich intelektualistów, możemy dostrzec podwójne rozliczenia z Holocaustem. Pierwsze, powojenne rozliczenie odnosi się do niemieckiej/hitlerowskiej rzeczywistości — Niemcy i ruch nazistowski stają się przedmiotem wiwisekcji. Drugie rozliczenie możemy natomiast umiejscowić w połowie lat 60. XX w., po „wielkim milczeniu” lat 50. $\mathrm{XX}$ w. - wówczas Zagłada zostaje wpisana w uniwersalne dzieje ludzkości, de facto $\mathrm{w}$ dzieje zbrodni. Na drugie rozliczenie nakłada się tzw. komercjalizacja Zagłady, wpisanie Shoah w kulturę masową ${ }^{37}$. Jednocześnie gros żydowskiej elity przyjmuje paremię nr 614, nakazującą przezwyciężyć pamięć o Holocauście ${ }^{38}$; przynajmniej w sferze publicznej nie ujawnia się piętna stale obecnej przeszłości. Do powyższej grupy zaliczyć można także Frankla39.

Tragiczne doświadczenia współczesnego świata stają się bezpośrednią przesłanką do krytyki nowożytności. Frankl nawiązując do psychoanalizy, postrzega człowieka w kilku wymiarach, przy czym autor Nieuświadomionego Boga odrzuca Freudowskie ujęcie ${ }^{40}$, przesuwa relację między id a ego i nadaje nową interpretację poszczególnym częściom struktury osobowości. Frankl przyjmuje kategorię autonomii jednostki, opowiada się za rygoryzmem moralnym, co „po Auschwitz” wydaje się jak najbardziej zrozumiałym. Człowiek w ujęciu Frankla jest rozciągnięty pomiędzy wolnością, która niestety może prowadzić do zdegenerowania (homunkulus ${ }^{41}$ ), a przemocą strukturalną, determinizmami społeczno-biologicznymi, które zdejmują z człowieka odpowiedzialność. Frankl „po Holocauście” zarówno kwestionuje pełną wolność człowieka, jak i odrzuca deterministyczne „uwięzienie” (biologiczne, ekonomiczne, społeczne), natomiast silnie wiąże człowieka z Bogiem, pierwotną etycznością. Nie pozbawia człowieka odpowiedzialności, a więc i winy, i kary, by przywołać poetykę Fiodora Dostojewskiego, którego poglądy Frankl podziela. Kategorie wolności, odpowiedzialności i winy są fundamentem antropologii Franklowskiej. Autor Człowieka wolnego przyjmuje również tezę Nicolaia Hartmanna o ,autonomii mimo zależności”, którą często w pracach przytacza. Jednocześnie odrzuca homunkulusa, jak pisał: „coś

37 Powszechnie uważa się, iż książka J. Kosińskiego, Malowany ptak (wydanie amerykańskie z 1965 r.) zapoczątkowała komercjalizację Holocaustu w kulturze masowej; J.P. Sloan, Jerzy Kosiński. Biografia, Warszawa 1997. Zob. interesującą pracę B. Kwieciński, Obrazy i klisze. Między biegunami wizualnej pamięci Zagłady, Kraków 2012.

38 E.L. Fackenheim, 614. Przykazanie, [w:] Teologia i filozofia żydowska wobec Holocaustu, op. cit., s. 335-340.

39 Zdaniem E. Hoerning przeszłe doświadczenia pojawiają się ,ponownie w zrewitalizowanych i uaktualnionych formach" (eadem, Rola wydarzeń życiowych: doświadczenia i rewitalizacja w perspektywie biograficznej, [w:] Metoda biograficzna w socjologii, op. cit., s. 132).

40 S. Freud, Poza zasada przyjemności, Warszawa 1976; idem, Kultura jako źródło cierpień, Warszawa 1992.

${ }^{41}$ Homunkulus jest efektem eksperymentu doktora Fausta poszukującego „nowego” człowieka. Zob. J.W. Goethe, Faust, t. II, Warszawa 1977, akt 2, scena w Laboratorium, s. 281-288, wiersz 6834-7019. 
sztucznego, produkt jakiegoś zawężonego i ograniczonego sposobu widzenia"42. Sprowadza homunkulusa do przedmiotu, odmawia mu prawa człowieczeństwa, dostrzega jego alienację antropologiczną. Krytyka homunkulusa jest pośrednią krytyką człowieka faustowskiego, a także nowożytnego humanizmu. W jego opinii humanizm usytuował człowieka w centrum świata i uczynił z niego Pana Świata. Holocaust dowiódł jednak, że człowiek takim panem stać się nie może.

Frankl jednocześnie dokonuje krytyki źródeł nowoczesności. Na określenie nowoczesności używa terminu „nowożytność”, co nie jest przypadkowe. Zamierza bowiem wskazać „błąd antropologiczny” (choć nie posługuje się powyższym terminem) całego współczesnego świata, chce zanegować jego źródła intelektualne i etyczne. Wypowiada się więc za radykalnym zerwaniem z pozytywistycznym myśleniem, owymi -izmami: fizjologicznymi, psychicznymi, społecznymi. Frankl celowo używa określenia -izmy, aby podkreślić ograniczony poznawczo charakter poszczególnych nurtów myślenia. Stylistyka -izmów ma podkreślić redukcjonistyczne ujęcie człowieka przez poszczególne kierunki w nauce i filozofii.

Frankl dostrzega ideę pozytywistyczną już we wczesnej nowożytności. Nie oznacza to odrzucenia postępu cywilizacyjnego, ale jego radykalne zakwestionowanie w warstwie antropologicznej. Nie porzuca nauki opartej na empirycznych badaniach (sam jest przecież przedstawicielem nauki przyrodniczej), natomiast kwestionuje tezy sytuujące człowieka w centralnym punkcie.

Bezpośrednio z krytyki nowożytności wyrasta Franklowska koncepcja antropologiczna. Człowiek jest postrzegany przez Frankla w czterech wymiarach: biologicznym, psychicznym, noologicznym/duchowym (odnoszącym się tylko do człowieka) i teologicznym, odnoszącym się tylko do Boga. Frankl nie precyzuje teologicznego wymiaru, po prostu jest on poza przedmiotem jego dociekań jako naukowca. Obok wymiarów biologicznego i psychicznego, tak charakterystycznych dla psychoanalizy, wprowadza także wymiar duchowy, który obejmuje swoiście ludzkie zjawiska, takie jak ,poszukiwanie sensu” (wyrażenie Frankla), podstawowe antropologiczne pytanie człowieka. Frankl wyraźnie więc nawiązuje do psychologii indywidualnej Adlera ${ }^{43}$, dokonując jej reinterpretacji. Powiązanie wymiaru noologicznego z działaniem człowieka umożliwia Franklowi podjęcie badań naukowych nad duchowością współczesnego człowieka. Staje się jednym z ważnych elementów uzasadnienia koncepcji i nową refleksją nad duchowością człowieka, formułowaną nie przez spekulatywną filozofię, czy teologię, ale przez empirystę, przedstawiciela nauk przyrodniczych, lekarza. Frankl wpisuje duchowość w badania nowoczesnej nauki. Formułuje nawet ideę posłannictwa duchowego psychiatrii, dokonując rozgraniczenia duszpasterstwa na medyczne i religijne ${ }^{44}$.

\footnotetext{
42 V.E. Frankl, Homo patiens..., s. 96.

43 A. Adler, Sens życia, Warszawa 1986.

44 V.E. Frankl, Homo patiens..., s. 109-117.
} 
Postulat wielowymiarowości człowieka jest moim zdaniem apelem Franklowskiej antropologii „po Auschwitz”, postulującej uznanie duchowości człowieka, przyznanie noologicznemu wymiarowi zasadniczego znaczenia i budowania wokół niego modelu człowieka. Postulat wielowymiarowości człowieka ma także dla niego wymiar praktyczny — porządkuje obszary badawcze, natomiast nie oznacza uznania poszczególnych wymiarów za równoważne ${ }^{45}$. Wielowymiarowość jest na poziomie semantycznym, a nie aksjologicznym, ponadto w mojej ocenie postulat wielowymiarowości wpisuje się w retorykę, a nie w jego wizję teoretyczną.

Frankl definiuje religijność/duchowość ${ }^{46}$ jako pytanie o sens ostateczny człowieka. Na potwierdzenie swoich słów przytacza opinię Alberta Einsteina o życiu jako poszukiwaniu sensu. Jak należy zatem rozumieć sens we Franklowskiej antropologii? Sens, termin wyjątkowo często przywoływany przez autora Homo patiens, nigdy nie został przez niego teoretycznie zdefiniowany. Raczej mamy do czynienia z opisem mieszczącym się na poziomie kozetki psychoanalityka, pewnego typu zamierzoną niedookreślonością. Poszukiwanie sensu przełożone na język potoczny (i kliniczny) sprowadza się do pytań: kim jesteśmy, dokąd zmierzamy i dlaczego?

Według Frankla wiara jest ufnością w sens ostateczny. Twórca logoterapii, dla swoich potrzeb lekko ważący siatkę pojęciową nauk o człowieku, stawia znak równości między wiarą a religią, w najszerszym klasycznym sensie (pierwsza filozofia w Arystotelesowskiej klasyfikacji). Frankla interesuje moment ujawniania się duchowości w człowieku w sytuacji egzystencjalnie skrajnej, jako zapory etycznej, a nie moment pojawienia się „żywego” kościoła, religii. W artykule duchowość odnoszę do tego, co jednostkowe, wewnętrzne (transcendentne), a religijność do tego, co ujawnia się na zewnątrz, do kultu. Dla Frankla religia/wiara jest stale obecna w człowieku, ale niekiedy jest ,zakryta”. Skupienie się Frankla na momencie granicznym odczytuję nie tylko jako konsekwencję tragicznego doświadczenia osobistego, powtórzmy - doświadczenia Holocaustu, ale także jako skutek tragicznego doświadczenia jego pacjentów. Dla Franklowskiej koncepcji „nieuświadomionego Boga” moment graniczny jest kluczowy jeszcze z jednego punktu widzenia. Ujawnienie momentu granicznego powoduje przekroczenie $\mathrm{Ru}-$ bikonu medycznego i religijnego, przyczynia się do rozpoznania libido, instynktu, tego, co pierwotne ${ }^{47}$. Przy tym Frankl nie rozpoznaje id jako pozostałości biologicznej, tylko jako przedkulturowy przedsionek. Frankl głosi „,przedmoralne poczucie sensu", które lokuje w nieświadomości ${ }^{48}$. Transcendencja duchowa

45 Zgadzam się z L. Witkowskim, który wielowymiarowość uznaje za jeden z mitów nauki.

46 Frankl używa obydwu wyrażeń zamiennie.

47 Twórca trzeciej szkoły psychiatrii wiedeńskiej zapożycza się intelektualnie u psychoanalityków (na poziomie metody), którzy szczególne znaczenie nadają momentom niezwykłym w biografii, wynaturzeniom - w przypadku Frankla są to momenty graniczne.

48 V.E. Frankl, Bóg ukryty..., s. 157. 
jest dla niego czymś pierwotnym, znajdującym się w podstawowym wyposażeniu człowieka. Jednocześnie Frankl zwraca uwagę na trzy, jego zdaniem błędne, dotychczasowe rozumienia nieświadomości: panteistyczne, okultystyczne i archetypiczne w interpretacji Carla G. Junga ${ }^{49}$.

Zdaniem Frankla w „głębi nieświadomości każdego człowieka tkwi bowiem głęboko zakorzenione poczucie religijności" ${ }^{50}$. W jego opinii poczucie religijności może „dojść do głosu” niespodziewanie, nawet w przypadku ciężkich chorób psychicznych, takich jak np. psychoza. Przy tym nieświadomość religijna nie jest popędowa, ale egzystencjalna ${ }^{51}$. Instynkt religijny jest pomostem między świadomością religijną a człowiekiem. Poczucie religijności (Frankl zamiennie używa określeń instynkt religijny i sumienie ${ }^{52}$ ) jest funkcją miłości/empatii do Drugiego, jest synonimem człowieka etycznego. Porzucenie uczuć jest porzuceniem także człowieczeństwa, a tym samym i Boga; wówczas staniemy się albo purchawkami (wyrażenie Frankla), albo homunkulusami, niemoralnymi tworami. Drugi w moim przekonaniu jest właśnie ideą „nieuświadomionego Boga”.

Kim jest zatem „nieuświadomiony Bóg” albo w późniejszej wersji książki „Bóg ukryty” ${ }^{53}$ Frankl w 1948 r. pisał:

choćby nieświadomie, ale zawsze kierujemy się intencjonalnie ku Bogu, że pozostajemy, jeśli nawet w nieświadomym, to zawsze intencjonalnym odniesieniu do Boga. I tego Boga właśnie nazywamy Bogiem nieuświadomionym ${ }^{54}$.

Zasadnicza polemika Frankla z psychoanalizą dotyczy rozumienia „nieświadomości”, która nie jest popędową siłą jak u Junga (a także Freuda), ale ma charakter osobowy — „decyzyjny”55. W słowie „decyzyjny” (Frankl zapisuje w cudzysłowie) zawarta jest autonomia człowieka, jego wolna wola, ego, a nie nierefleksyjne, popędowe id. W osobowym ego ujawnia się „decyzyjność”. Tego typu usytuowanie jest w przekonaniu Frankla możliwe tylko na gruncie koncepcji analizy egzystencjalnej, a nie psychoanalizy.

49 V.E. Frank1, Nieuświadomiony Bóg, Warszawa 1978, s. 58-64; idem, Bóg ukryty..., s. 8490. Zob. C.G. Jung, Archetypy i symbole. Pisma wybrane, Warszawa 1993.

50 V.E. Frankl, Bóg ukryty..., s. 24.

51 Powyższy aspekt nie jest rozważany.

${ }^{52}$ Frankl dosyć swobodnie operuje siatką pojęciową nauk humanistycznych; instynkt religijny jest propozycją przywoływaną w kontekście psychoanalizy, natomiast sumienie w rozważaniach nawiązujących do etyki.

53 Wyrażenie ,ukryty Bóg”, zaczerpnięte z angielskiego tytułu wydania już po śmierci Frankla, jest wyrażeniem biblijnym (Księga Izajasza; także Psalmy). Co ciekawe, zbiór poezji K. Wojtyły nosi tytuł Pieśń o Bogu ukrytym: poezje (Warszawa 1998).

54 V.E. Frankl, Nieuświadomiony Bóg..., s. 57. Powyższą definicję powtórzył w pracy Bóg ukryty (s. 84).

55 Zasadniczą różnicą między wersją koncepcji „nieuświadomionego Boga” z 1948 r. a 1975 r. jest wyeksponowanie wątku „decyzji” i działania w rozważaniach o sumieniu; dla rozważań o Holocauście nie aż tak bardzo istotnym. 
Nieświadomość religijna nie może być dziedziczona (dlatego odrzuca umieszczenie jej w id), ale może być przekazywana kulturowo, przez tradycję ${ }^{56}$. Dlatego w ocenie Frankla

\begin{abstract}
wszelka religijność korzysta z wcześniej wytyczonych dróg i gotowych schematów rozwoju. [I w mojej ocenie kluczowy fragment - M.N.] Nie są one jednak wrodzonymi, dziedzicznymi archetypami [jak u Junga], lecz istniejącymi formami [kultu], w które wlewamy swoją indywidualną religijność. Formy te nie są nam przekazywane w rozumieniu biologicznym, ale jako tradycyjne symbole charakterystyczne, dla danej kultury [...] Istnieją [...] gotowe formy religijne, oczekujące aż człowiek egzystencjalnie je sobie przyswoi, to znaczy uczyni swoimi własnymi ${ }^{57}$.
\end{abstract}

Powyższy fragment można interpretować następująco: człowiek zaprasza transcendencję, która się w nim rozwija dzięki istniejącym formom kultu/kościołom.

Koncepcja „nieuświadomionego Boga” jest pytaniem o człowieka w świecie totalitarnym, o granicę ludzkiej etyczności. Frankla interesuje moment porzucenia etyczności przez człowieka i powrotu do świata zwierząt (homunkulus) — w tym sensie nadal interesuje go moment graniczny popelnienia samobójstwa, lecz już nie moment psychiczny, tylko duchowy. Kontynuuje więc medyczne rozważania o samobójstwie, ale posiłkując się koncepcją analizy egzystencjalnej, sięga po antropologią filozoficzną. Frankl formułuje nawet bardzo drastyczną w swojej wymowie opozycję między lekarzem i weterynarzem, od spraw ludzkich ${ }^{58}$. Opozycję zrozumiałą tylko w kontekście osobistych przeżyć Frankla, więźnia Auschwitz. Franklowską opozycję możemy wyczytać ze wspomnień także innych więźniów obozów koncentracyjnych (np. T. Borowski, P. Levi). Sprowadzenie człowieka do świata zwierząt skutkuje tragicznymi konsekwencjami: eutanazją i Holocaustem.

Frankl formułuje z perspektywy filozoficznej humanistyczną ideę lekarza „po Auschwitz" jako opozycję do weterynarza (w wersji radykalnej) albo do technika, ujmującego człowieka w duchu mechanistycznych koncepcji oświeceniowych jak ironizująco stwierdza Frankl: lekarz-technik od naprawy „mechanizmów” (co jest kolejną wyraźną aluzją i polemiką z Freudowską psychoanalizą, jak i pozytywistyczną nauką). Lekarz-humanista postrzega pacjenta nie tylko przez pryzmat biologiczno-psychologicznych mechanizmów, ale także noologicznych. Uwzględnienie czynnika duchowego w praktyce lekarskiej staje się podstawą do sformułowania idei posłannictwa lekarza. Frankl formułuje filozoficzny ideał misji lekarza, głosi nawet ideę duszpasterstwa lekarskiego ${ }^{59}$.

Zdaniem Frankla psychoanaliza przyjęła mechanistyczny obraz człowieka w dużej mierze pod wpływem nacisku ówczesnego klimatu intelektualnego epoki, czasu znacznych osiągnięć cywilizacji przemysłowej — w jego opinii Freud uległ presji współczesności. Frankl formułuje nawet zarzut manipulacji pod adresem

\footnotetext{
${ }^{56}$ Frankl formułuje analogiczną tezę jak: J. Searle, J. Austin odnośnie języka.

57 V.E. Frankl, Bóg ukryty..., s. 89; idem, Nieuświadomiony Bóg..., s. 62.

58 V.E. Frankl, Psychoterapia dla każdego..., Warszawa 1978.

59 Idem, Bóg ukryty..., s. 97.
} 
psychoanalizy, ale powyższy zarzut zostanie także jemu postawiony ${ }^{60}$. W ocenie Frankla psychoanaliza burzy „to, co jest w człowieku jednolitą całością, stawiając sobie w końcu za zadanie zrekonstruowanie go z poszczególnych części”"61. Owe burzenie dotyczy rozłożenia osobowości człowieka na trzy odrębne części (id, ego i superego), co prowadzi jego zdaniem do depersonalizacji człowieka, sprowadzenia człowieka do fragmentów psychicznych i fizjologicznych. Oczywiście ponowne złożenie może również prowadzić do niebezpieczeństwa manipulowania osobowością, jednak Frankl nie podejmuje powyższego wątku, głównego dla szkół psychiatrii wywodzących się z psychoanalizy. Pod adresem Frankla pojawią się zarzuty o balansowaniu przez logoterapię na granicy perswazji, czy narzucaniu sensu, co jest oceniane jako działanie autorytarne. Frankl ma świadomość wagi zarzutów, dlatego manipulacji ma przeciwdziałać świadome wychowanie do odpowiedzialności ${ }^{62}$. Balansuje on więc na granicy „błędnego koła”. Moment ponownego złożenia struktury osobowości (odnoszę się do treści owego złożenia) jest momentem, w mojej ocenie, wyraźnie politycznym, ponieważ podejmuje zagadnienia hierarchii wartości. Poszukiwanie sensu, celu i zadań jednostki hic et nunc określa postawę wobec świata, tym samym definiuje człowieka ideologicznie. Jest to moment, gdy psychiatra zdobywa „władzę klucznika”, dysponuje kluczem do duszy. Jak pisał w Homo patiens, posiada władzę duchową ${ }^{63}$, którą z pełnym przekonaniem chce mieć i nieść, ponieważ politycy w jego opinii nie podołali zadaniu (Holocaust). Frankl formułuje pod adresem polityki bardzo krytyczne sądy — oskarża polityków o makiawelizm i cynizm.

Jego zdaniem psychoanaliza przyjmuje atomistyczną, energetyczną i mechanistyczną koncepcję człowieka. Postrzega człowieka w ostatecznym rozrachunku jako automatycznie działający aparat psychiczny. Frankl odrzuca tego typu podejście i proponuje skupienie się na „autonomii egzystencji duchowej”. Analiza egzystencjalna w jego opinii odkryła nieuświadomioną religijność człowieka (instynkt etyczny/sumienie), tak jak psychoanaliza odkryła nieświadomą popędowość (sferę libido/id).

W jego ocenie granica między świadomym i nieświadomym ,jest niezwykle płynna, wręcz przepuszczalna”. Frankl odrzuca dominację „nieświadomego id" nad ,świadomym ego". Przeciwstawia się fatalizmowi popędów, tzw. neurotycznemu fatalizmowi pacjenta. W jego opinii „ludzka egzystencja ze swej istoty wymyka się refleksji, podobnie jak »ja« samo w sobie. Byt ludzki »egzystuje« w działaniach, a nie w refleksji”' ${ }^{\prime 2}$. Rolą człowieka nie jest więc formułowanie pytania dotyczącego sensu własnego życia, lecz odpowiedź na pytanie o sens poprzez działanie. Aktywistyczne podejście niesie jednak słabości, których wydaje

\footnotetext{
${ }^{60}$ M. Nieć, op. cit., s. 158-159.

61 V.E. Frankl, Bóg ukryty..., s. 39; por. idem, Nieuświadomiony Bóg..., s. 9.

62 V.E. Frankl, Bóg ukryty..., s. 148.

${ }^{63}$ Idem, Homo patiens..., s. 42.

${ }^{64}$ Idem, Bóg ukryty..., s. 49.
} 
się, iż Frankl nie rozwiązuje — albo „po Holocauście” nie chce rozwiązań — ufa człowiekowi, ale jednocześnie także się go obawia. Jak już zostało wspomniane — stawia go między „spętanym aniołem” a „szlachetną bestią”. Samoświadomość i refleksja jest niezbędna do odpowiedzialnego postępowania, oderwania się od sytuacji granicznej, z drugiej strony Frankl nakazuje działanie, które w ostatniej instancji jest instynktowne, nieświadome. Tym samym zdaje się ograniczać wolną wolę i odpowiedzialność człowieka. Ma świadomość powyższych słabości teoretycznych, w poszukiwaniu koncepcji kieruje się w stronę pedagogiki (pedagogi) $^{65}$. Apel „bądź panem swojej woli i sługą swojego sumienia” nie rozwiązuje jednak problemu. Wydaje się tylko zgrabną metaforą.

Frankl formułuje również teorię sumienia, istotną dla jego koncepcji „nieuświadomionego Boga", będącą dopełnieniem jego rozważań antropologicznych. Teoria ta wyrasta bezpośrednio z analizy egzystencjalnej, jego refleksji filozoficznej o życiu społecznym, natomiast instynkt religijny/artystyczny jest przedmiotem zainteresowania logoterapii. Frankl w zależności od oglądu sięga albo po teorię sumienia/analizę egzystencjalną (etyczną analizę życia), albo „poszukuje” instynktu religijnego w logoterapii. Twórca trzeciej szkoły wiedeńskiej stara się ujmować człowieka z obydwu oglądów jednocześnie - przynajmniej na poziomie opisu - co prowadzi do pewnego zamieszania metodologicznego. Przekładanie pojęć z różnych nauk lub implementacja często skutkuje bowiem słabościami teoretycznymi lub zbyt daleko idącymi wnioskami i pochopnymi tezami. Dotyczy to także Frankla.

Przedstawmy zatem Franklowską koncepcję sumienia, poddając ją krytycznej analizie. „Sumienie bowiem” — w jego przekonaniu — „sięga najgłębszych pokładów nieświadomości i wyrasta na gruncie nieświadomości” i zasadniczy fragment: „decyzje najbardziej doniosłe i autentyczne - autentyczne egzystencjalne - zapadają właśnie w sposób bezrefleksyjny, a zatem nieświadomy"66. Frankl dokańcza cytowany akapit następującym passusem: „Sumienie jest u swego źródła zanurzone w nieświadomości”. W moim przekonaniu w tym miejscu ukazuje się Frankl spętany w psychoanalitycznej retoryce. Nie bardzo jest zrozumiałe, dlaczego bezrefleksyjność ma zostać sprowadzona do nieświadomości. $\mathrm{Na}$ poziomie potocznego języka tego typu opis jest dopuszczalny, ale nie na poziomie nauki - jest zbyt daleko idącym uproszczeniem.

Sumienie dla Frankla jest „przedlogiczne”, co argumentuje, podając, że jeśli istnieje przedlogiczne rozumienie bytu, ,tak też istnieje przedmoralne rozumienie sensu, czyli właśnie sumienie" ${ }^{97}$. Wydaje się jednak, iż analogia ta nie może być dowodem, a jedynie pewną supozycją, założeniem wstępnym i tak też należy odczytywać propozycję intelektualną Frankla. Koncepcję sumienia odczytuję jako hipostazę, co niesie określone konsekwencje teoretyczne.

65 J.T. Michalski, op. cit.

66 V.E. Frankl, Bóg ukryty..., s. 53.

67 Ibidem. 
Przedmoralne rozumienie sensu zostaje więc człowiekowi dane wraz z jego duchowym wyposażeniem, a zatem - w przekonaniu Frankla — nie istnieje początkowy moment definiowany w określonej aksjologii. W tym znaczeniu sumienie nie jest uwarunkowane moralnie, ale jest przedmoralnym instynktem. W dodatku sumienie wymyka się racjonalizacji; zdaniem Frankla raczej odkrywa to, co powinno być etyczne, niż to, co jest. Powinnościowy charakter sumienia kieruje je w stronę indywidualnie przypisanej intuicji, a nie w stronę praw moralnych w rozumieniu Kantowskim. Frankl w cytowanym fragmencie przywołuje koncepcję „prawa indywidualnego” Georga Simmela, socjologa i filozofa. W mojej ocenie, ujmując sprawę bardzo potocznie, Frankl wykonuje szpagat między psychoanalizą a paremią żydowską, po drodze wrzucając do filozoficznego worka różne propozycje fizjologów (K. Lorenz), socjologów (G. Simmel) oraz antropologów (M. Scheler), tworząc eklektyczną intelektualnie figurę teoretyczną ${ }^{68}$.

W opinii Frankla Bóg jest źródłem miłości, podczas gdy instynkt etyczny jest funkcją wiary, a sumienie - ostatnią instancją rozstrzygającą. Zdaniem Claudii Hammond Frankl proponuje cierpienie przemienić w triumf, poczucie winy w pracę nad sobą, a świadomość nieuchronnego końca — w bodziec do działania ${ }^{69}$.

Rozwijając kwestię sumienia, należy podkreślić, że zdaniem Frankla sumienie jest instynktem etycznym, który jest nakierowanym na to, co indywidualne i konkretne, w przeciwieństwie do instynktu biologicznego, nakierowanego na to, co gatunkowe i powszechne. W jego ocenie

instynkt etyczny [i tylko on jeden — M.N.] pomaga człowiekowi odkryć jedyną powinność możliwą do spełnienia $\mathrm{w}$ danej sytuacji [...] Wyłącznie sumienie pozwala nam dostosować „odwieczne”, powszechnie przyjęte prawo moralne do konkretnych okoliczności ${ }^{70}$.

Zdaniem Frankla istnieje także sumienie artystyczne.

W ocenie Frankla

duchowe ,ja” jest zanurzone w swojej nieświadomej głębi, tam rodzą się takie zjawiska, jak sumienie, miłość oraz sztuka. Tam zaś gdzie jest odwrotnie — to znaczy, gdzie psychofizyczne id wdziera się do świadomości - tam mamy do czynienia z nerwicą albo psychozą, w zależności od tego, czy podłoże danego zaburzenia jest psychogenne czy somatogenne ${ }^{71}$.

Frankl wpisuje zatem koncepcję nieuświadomionego Boga we Freudowską psychoanalizę, sumienie przypisując do tego, co kulturowe (ego), zaś amoralność do tego, co pierwotne, biologiczne (id). Jednocześnie jako lekarz wskazuje na zależność choroby psychicznej od dominacji id w strukturze osobowości. Takie ujęcie id stwarza określone problemy — nie pozwala bowiem na udowodnienie centralnej tezy o instynktownym ujawnianiu się moralności, a także tezy o wyposażeniu

68 V.E. Frankl, Homo patiens..., s. 25.

69 C. Hammond, Przedmowa, [w:] V.E. Frankl, Bóg ukryty..., s. 11.

70 V.E. Frankl, Bóg ukryty..., s. 56.

71 Ibidem, s. 60. 
moralnym człowieka, jakiegoś typu moralności generatywnej ${ }^{72}$. Psychiatra ma pełną świadomość słabości teoretycznej koncepcji „nieuświadomionego Boga”, formułowanej na gruncie psychoanalitycznego myślenia; prawdopodobnie zakładał przezwyciężenie teoretycznych słabości w kolejnych publikacjach.

Praca Frankla powstała w 1948 r. w określonym czasie historycznym i politycznym, jednakże późniejsze prace nie przybliżają go do rozwiązania problemu. Sformułowanie Frankla z 1975 r., przytaczane we wstępie artykułu, raczej wskazuje na odejście od koncepcji. Określenie „Bóg ukryty” jest powrotem do biblijnego ujęcia, eksponuje bardziej etyczną koncepcję, a nie psychoanalityczne ujęcie.

Frankl w przedmowie do książki Człowiek w poszukiwaniu ostatecznego sen$s u$ (polskie wydanie Bóg ukryty. W poszukiwaniu ostatecznego sensu ${ }^{73}$ ) formułuje nawet polityczne przesłanie, wykazując znaczne, jak na psychiatrę, zaangażowanie polityczne. Choć jak pisał, nie interesuje go religia instytucjonalna i kościoły wyznaniowe, krytykuje je za zbyt wąskie traktowanie religii. Jego zdaniem sprowadzają one religię do głoszenia kultu Boga objawionego i nakazują wiarę, nadzieję i miłość. W opinii Frankla nie można nakazać miłości czy zmusić do nadziei. Twórca trzeciej szkoły psychiatrii wiedeńskiej podkreśla również manipulacyjny charakter wielu Kościołów. Bardzo krytycznie pisał: „Jeżeli lepiej się temu przyjrzeć, okazuje się, że za wszelkimi próbami wymuszania siłą wiary, nadziei, miłości oraz aktów woli kryje się zwykła manipulacja"74. Obrusza się też na zmuszanie ludzi do przyjęcia wiary, poprzez analogię - jego zdaniem nie można zmusić człowieka do śmiechu, ale można go rozśmieszyć. Polemizuje zatem (bez wskazania oponenta) z Augustiańskim nawoływaniem „zmuście ich”. W ocenie Frankla tylko poprzez etyczne postępowanie można rozbudzić wiarę człowieka.

Frankl nie jest teologiem, więc nie kładzie akcentu na doktrynę, ale na zgodność wizji z praktyką. Istotną rolę przypisuje działaniu, uczynkom w Pawłowym rozumieniu. Pisał w Bogu ukrytym: „nie możemy się ograniczyć do nauczania w zgodzie z wytycznymi danego Kościoła [...] musimy przedstawić wiernym swojego Boga w sposób wiarygodny — i samemu być dla nich wiarygodnym"75. W ocenie polityki współczesnych Kościołów jest bardzo krytyczny. W mojej opinii poniższe słowa możemy nie tylko odnieść do współczesności, lecz także do bliskiej przeszłości, szczególnie do polityki Kościołów wobec państw totalitarnych i Holocaustu. Zdaniem Frankla Kościoły bowiem „zachowują się tak, jakby głównym celem ich wyznania była dominacja nad innymi wyznaniami”"76. Pobrzmiewa tu zatem zarzut wojny religijnej i walki z judaizmem, ciągle aktualne

72 Określenie formułuję na wzór koncepcji gramatyki generatywnej Chomsky’ego, który zakładał wyposażenie lingwistyczne człowieka; por. przypis 56.

73 Tłumaczenia prac Frankla w Stanach Zjednoczonych otrzymywały z reguły inne tytuły, co nie jest tylko drobną zmianą stylistyczną, ale inną interpretacją.

74 V.E. Frankl, Bóg ukryty..., s. 29.

75 Ibidem.

76 Ibidem, s. 30. 
echo oskarżenia Kościołów chrześcijańskich o antysemityzm. Trzeba jednak zaznaczyć, że jednocześnie Frankl jest zwolennikiem polityki aggiornamento Jana XXIII i Pawła VI oraz ruchu ekumenicznego.

Warto w tym kontekście przypomnieć kilka faktów z biografii Frankla. Pierwszy doktorat honoris causa nadaje Franklowi Loyola University w Chicago (1970 r.); następnie honorowe doktoraty przyznają mu inne uczelnie katolickie, m.in. Katolicki Uniwersytet Lubelski, obecnie im. Jana Pawła II (1994 r.). W katolickich ośrodkach tworzone są instytuty logoterapii, podejmujące koncepcje Frankla i rozwijające je (w Polsce szkoła ks. prof. K. Popielskiego ${ }^{77}$ ). Na audiencji generalnej papież Paweł VI wymienia z imienia Frankla, podkreślając jego zasługi.

Kościoły walcząc o dominację, stają się strażnikami kultu — Frankl osłabia powyższy zarzut przez zastrzeżenie, że Kościół jest tak często postrzegany. Jednocześnie odrzuca ideę uniwersalnej religii. Jego zdaniem religia uniwersalna nie zapanuje na świecie, a wprost przeciwnie - religia, żeby mogła przetrwać (tak u Frankla ${ }^{78}$ ), musi „zostać głęboko spersonalizowana”. Przewiduje w związku z tym większą indywidualizację postaw religijnych. Nie sądzi jednak, by nastąpiło odrzucenie symboli i rytuałów (kultu); w innym fragmencie uzna symbole i rytuały za przedsionek wiary. „Wiara w Boga bowiem, albo jest bezwarunkowa, albo wcale nie jest wiarą"79 — dlatego zarówno Holocaust (śmierć $6 \mathrm{mln}$ ), jak i śmierć jednego (w teologicznym oglądzie Talmudu) mogą być rozpatrywane na jednej płaszczyźnie ${ }^{80}$.

W zarzutach wobec polityki Kościoła można dostrzec raczej osobiste emocje, jakieś pretensje, może nawet i uzasadnione. Krytyka instytucjonalnego Kościoła jest Franklowi potrzebna do wykazania celowości podejmowanych przez niego jako psychiatrę działań, która w pomysłach autora Nieuświadomionego Boga wkracza w obszar „pozostawiony” przez Kościół instytucjonalny. Frankl rozdziela politykę Kościoła od głoszonej przez Kościół ewangelii. Powtórzmy, w ,sytuacji granicznej” (w Auschwitz, ale i w sytuacji samobójstwa) nie ma Kościoła instytucjonalnego, jest tylko Bóg i instynkt moralny.

Frankl odpowiedzialnością za kondycję współczesnego człowieka obarcza środowisko polityczne, które jest winne thumieniu instynktu etycznego, co możemy odczytywać jako polemikę z Weberowskim ujęciem polityki jako socjotechniki sprawowania władzy. Frankl sięga więc po argument klasycznej nauki o polityce o wpływie politei na paideę (Platon, Arystoteles). W tym momencie dostrzega on już w człowieku raczej „spętanego anioła” niż „szlachetną bestię"81,

${ }^{77}$ K. Popielski sformułował własną koncepcję noetyczną; zob. Człowiek - wartość - sens, red. K. Popielski, Lublin 1996.

78 Powyższa opinia jest sprzeczna z jego wcześniejszymi poglądami — jest prawdopodobnie figurą retoryczną.

79 V.E. Frankl, Bóg ukryty..., s. 30.

80 V.E. Frankl, Homo patiens..., s. 95; Frankl przytacza znany fragment Talmudu: „Kto zniszczy choćby jedną duszę, podobny jest temu, kto by zniszczył cały świat, a kto jedną duszę ratuje, ten jakby ratował cały świat".

81 V.E. Frankl, Bóg ukryty..., s. 92. 
pomiędzy którymi wcześniej sytuował człowieka — ujawnia się więc optymizm Franklowski „po Auschwitz”. Jednocześnie nadal podejmowane próby ludobójstwa przez współczesnego człowieka wywołują u niego pytania o czynniki patologii ducha czasu ${ }^{82}$. We współczesności, ,po Auschwitz”, nadal dostrzega syndrom ludobójstwa. Stawia więc pytanie o przyczyny - czy jest to tylko antysemityzm (choć Frankl wprost nie formułuje tak pytania), czy może są inne przyczyny. Sam sobie odpowiada, powracając do Freuda - przyczyny tkwią w cywilizacji. Rozbicie tradycyjnego świata wspólnoty ujawnia tragiczność losu człowieka, jego osamotnienie i cierpienie. Nasuwają się skojarzenia z optymizmem tragicznym Emmanuela Mouniera. Formułując pesymistyczny obraz człowieka cierpiącego, Frankl nie kreśli jednak pesymistycznej prognozy, jako że przecież nawet „po Auschwitz" nastąpiło wzmocnienie religijności, a nie jej osłabienie. Cierpienie ma dla niego wymiar eschatologiczny i immamentny, możemy więc wskazywać na pewne fale cierpienia, większe lub mniejsze, uwarunkowane „duchem czasu”. Trzeba ponadto zaznaczyć, że w sformułowaniu „duch czasu” kryje się odniesienie do historii, a nie do uniwersum.

Frankl jako najważniejszy czynnik patologii ducha czasu wymienia prowizoryczną postawę jednostki wobec życia. W jego opinii prowizoryczna postawa ujawnia się podczas wojny, ale także wówczas, gdy żyjemy tylko chwilą. Tego typu postawę można dostrzec we współczesnej demokracji. W opinii twórcy logoterapii wojna wzmaga zainteresowania dniem dzisiejszym, ponieważ ,człowiek nie widzi przed sobą przyszłości” i w konsekwencji ,upada” na duchu. Nie jest w stanie zachować swoich wartości, staje się chwiejny, łatwo ulega zachciankom i modom. Zaczyna zamieniać miłość na erotyzm rozkoszy. Pośrednio Frankl krytykuje więc Freudowską zasadę przyjemności.

Trzeba również podkreślić, że Frankl odnosi się nie tylko do II wojny światowej, lecz także do Wielkiej Wojny i do „zimnej wojny”. Jeśli prześledzimy biografię twórcy trzeciej szkoły psychiatrii wiedeńskiej (rocznik 1905), zauważymy, że wojna wypełnia większość jego dorosłego życia, ma bezpośredni wpływ na jego egzystencję i postępowanie.

Drugim czynnikiem mającym wpływ na patologię ducha czasu jest fatalistyczna postawa wobec życia, także związana z przeżyciami wojennymi. Zdaniem Frankla ludzie traktują się wzajemnie i sami są traktowani jak pionki, trybiki w większej machinie, są częścią nieokreślonej masy. Człowiek poddany jest indoktrynacji (,tresurze" - wyrażenie Frankla), pojawia się genetyczny fatalizm. Panuje przekonanie, że los człowieka został zapisany w genach. Następuje ucieczka od odpowiedzialności. Powyższy opis odnosi się głównie do totalitaryzmu, choć dostrzec można inspiracje Frommowską ,ucieczką od wolności”. Frank1 używa jednak pojęcia faszyzm zamiast totalitaryzm, co nie jest

82 Czynniki patologii ducha czasu doczekały się dosyć obszernego omówienia w polskiej literaturze, co zwalnia mnie od szczegółowej prezentacji; por. J.T. Michalski, op. cit., s. 62-85. 
przypadkowe. Opisuje bowiem doświadczenia niemieckie, nakładając je na szersze tło. Dostrzega ucieczkę od odpowiedzialności nawet w demokratycznej cywilizacji północnoamerykańskiej. Dokonuje więc uniwersalizacji. W socjologii amerykańskiej stają się wówczas modne koncepcje „samotnego thumu”, silnie zanurzone w psychologizmie.

Trzecim czynnikiem rzutującym na patologie ducha czasu jest kolektywne myślenie, które przedkłada zbiorową odpowiedzialność nad jednostkowy rozwój osobowości. Zamiast kolektywnych uogólnień, które są dla Frankla charakterystycznym sposobem myślenia dla totalitaryzmu, potrzebujemy według niego integralnie uzupełniających się ludzi. Jednostkowy rozwój osobowości, wychowanie do sensu są Franklowską odpowiedzią na totalitarne myślenie człowieka masowego, poddanego indoktrynacji. Powyższa diagnoza odnosi się jednak do czasu minionego, ale nie przeszłego.

Czwartym bodźcem patologii ducha czasu jest fanatyzm. W ocenie Frankla osoba myśląca „kolektywistycznie ignoruje własną osobowość, rozpływając się w masie, albo raczej zatracając się w niej”"83. Pojawia się brak własnego zdania, ale także odpowiedzialności za czyny.

Poszczególne patologie sprzyjają, w opinii Frankla, pojawianiu się nerwic społecznych. I tak człowiekowi z prowizoryczną postawą odpowiada chory w stanie maniakalnym, fatalistyczna postawa sprzyja pojawieniu się chorych na melancholię, kolektywistyczna świadomość wytwarza schizofrenię katatoniczną, natomiast fanatyzm - paranoję.

Psychiatra dostrzega powyższe patologie także w demokracji, chociaż nie akcentuje ich silniej. Poprzez zrównanie czasu wojny (totalitaryzm jako osobiste doświadczenie i doświadczenie wielu) z czasem pokoju (demokracja jako codzienność życia) prawdopodobnie zmierza do nadania wskazanym patologiom powszechnego zjawiska nowoczesności. Frankl podejmuje jednocześnie krytykę nowoczesności „po Auschwitz”, dowodząc braku zmiany stanu świadomości ludzi. Oczywiście dostrzega pewne różnice, ale nie zasadnicze - oto nadal jesteśmy w czasie wojny, społeczeństwo jest silnie znerwicowane, a homo patiens potrzebuje pomocy.

Zdaniem Frankla „poznaliśmy już sztuczną karykaturę człowieka w trzech nihilistycznych ramach: biologizmu, psychologizmu i socjologizmu; znamy owo zoon politikon, owego homo faber i homo sapiens" ${ }^{84}$. Doświadczenie Holocaustu ujawniło wszystkie ograniczenia i słabości człowieka, dlatego człowieka doby nowoczesności nie można pozostawić samemu sobie, trzeba wskazać mu ogólną drogę postępowania. Jest co prawda miejsce na własną ścieżkę życia, ale należy silniej go związać z Bogiem (postulat etyczności), by zabezpieczyć świat i człowieka przed wynaturzeniami. Frankl apeluje nawet o przewrót Kopernikański

83 V.E. Frankl, Homo patiens..., s. 61.

84 Ibidem..., s. 82. 
w psychoterapii. Jego zdaniem pytanie o sens cierpienia jest bowiem pytaniem o sens życia. Człowiek musi odpowiadać na pytanie o sens życia, a nie pytać. W jego przekonaniu „samo życie jest pytaniem" ${ }^{85}$. Przywołuje centralną tezę filozofii egzystencjalnej i psychoanalizy, którą poddaje nowej interpretacji. W jego przekonaniu „byt ludzki jest ostatecznie cierpieniem [...] istotnym przeznaczeniem człowieka jest - cierpieć: być homo patiens". Powyższą prawdę podsumowuje stwierdzeniem ,człowiek cierpiący odkrywa poza dobrem i złem, pięknem i brzydotą" ${ }^{86}$. Ostatni passus jest polemiką z Fryderykiem Nietzsche, ale także z Freudowską psychoanalizą, wyraźnie do filozofii egzystencjalnej nawiązującą, ale poprzez Artura Schopenhauera.

Późniejsze prace Frankla i nowe wydania „starych” koncepcji zdają się potwierdzać jego pesymistyczne spojrzenie z pierwszych lat powojennych. Wydaje się, że tak przerażające doświadczenie Holocaustu niczego ludzkości nie nauczyło i nic jej nie uświadomiło. Nadal dochodzi do masowych zbrodni, mimo zaspokojenia potrzeb biologiczno-społecznych ludzie mają problemy z odnalezieniem sensu życia, fala samobójstw nie maleje. Pesymistyczna wizja rozwoju cywilizacji zmienia spojrzenie na Holocaust, sytuuje Zagładę w ciągu tragicznych wydarzeń, oczywiście nie podważając piętna. Frankl jest przede wszystkim lekarzem, ale lekarzem, który filozofuje w Sokratejsko-Platońskim rozumieniu, pozostaje zdziwionym, a może właściwie zadziwionym ludzką bezmyślnością ${ }^{87}$, brakiem pamięci historycznej, przy czym Frankl nie grzmi, nie straszy, nie stara się być kaznodzieją w białym kitlu. Stara się znaleźć lekarstwo. Ma nim być wychowanie do sensu i uświadomienie sensu życia.

Holocaust funduje filozofię moralną Frankla. Bez tragicznego doświadczenia Holocaustu psychiatra nie sformułowałby koncepcji „nieuświadomionego Boga” i nie podtrzymałby optymistycznej tezy etycznej o triumfie dobra, nawet „w i po Auschwitz”. Koncepcja „nieuświadomionego Boga” rodzi się jako koncepcja podsumowująca osobiste doświadczenie Holocaustu z propozycją uogólnienia na inne tragiczne doświadczenia. Holocaust jest dla Frankla próbą unieważnienia narodu żydowskiego, sprowadza się do zakwestionowania Żyda jako człowieka, pozbawiając go prawa do śmierci i etyczności, fundamentów człowieczeństwa. Holocaust nie zabija, ale unieważnia historię narodów, a tym samym biografię jego członków. Holocaust unieważnia naród żydowski, pozbawiając go prawa do cmentarza, miejsca kontemplacji etycznej jednostki, albowiem cmentarz zdaje się rewersem życia.

Jaka jest zatem jego odpowiedź na poszukiwanie sensu życia po Holocauście? Frankl nie daje jednoznacznej odpowiedzi. Określenie „po Holocauście” jest Franklowską polemiką z żydowskimi interpretacjami ,śmierci Boga w Auschwitz”, pesymistycznymi koncepcjami etyczności ludzi „po Auschwitz”.

85 Ibidem, s. 133.

86 Ibidem, s. 82.

87 Dla Frankla symbolem kolejnej ludzkiej bezmyślności jest Hiroszima. 
W koncepcji cierpienia Frankl uogólnia doświadczenie Holocaustu, stwierdzając, że cierpienie jest niezmienną właściwością ludzi, która wpisuje się w tragiczną triadę: cierpienie - wina - śmierć $^{88}$. Zatem cierpienie wpisuje się w sens życia. W jego ocenie „cierpienie ma nie tylko etyczną godność, lecz także wzniosłość metafizyczną" ${ }^{\circ 9}$. Sensem życia jest samo życie, zarówno w aspekcie etycznym (godność), ale także metafizycznym (Bóg). Oto odpowiedź praktycznego klinicysty na rozterki moralne filozofa i pytania człowieka cierpiącego.

\section{Bibliografia}

Adler A., Sens życia, Warszawa 1986.

Adorno T., Osobowość autorytarna, Warszawa 2010.

Chałubiński M., Fromm, Warszawa 1993.

Człowiek - wartość - sens. Studia z psychologii egzystencjalnej. Logoterapia i nooteoria, red. K. Popielski, Lublin 1996.

Durkheim E., Samobójstwo. Studium z socjologii, Warszawa 2006.

Frankl V.E., Bóg ukryty. W poszukiwaniu ostatecznego sensu, Warszawa 2012.

Frankl V.E., Człowiek w poszukiwaniu sensu, Warszawa 2009.

Frankl V.E., Homo patiens, Warszawa 1998.

Frankl V.E., Nieuświadomiony Bóg, Warszawa 1978.

Frankl V.E., Psychoterapia dla każdego, Warszawa 1978.

Freud S., Kultura jako źródło cierpień, Warszawa 1992.

Freud S., Poza zasada przyjemności, Warszawa 1976.

Fromm E., Anatomia ludzkiej destruktywności, Poznań 1999.

Fromm E., Niech się stanie człowiek. Z psychologii etyki, Warszawa-Wrocław 1994.

Fromm E., Ucieczka od wolności, Warszawa 1970.

Goethe J.W., Faust, Warszawa 1977.

Horney K., Neurotyczna osobowość naszych czasów, Poznań 1999.

Jonas H., Idea Boga po Auschwitz, Kraków 2003.

Jung C.G., Archetypy i symbole. Pisma wybrane, Warszawa 1993.

Kwieciński B., Obrazy i klisze. Między biegunami wizualnej pamięci Zagłady, Kraków 2012.

Metoda biograficzna w socjologii, red. J. Włodarek, M. Ziółkowski, Warszawa-Poznań 1990.

Michalski J.T., Sens życia a pedagogika. Impulsy myśli Victora E. Frankla, Torun 2011.

Nieć M., Cień Holokaustu w twórczości Victora Frankla i Jerzego Kosińskiego, [w:] Rodzina wychowanie w cieniu Holocaustu, red. A. Łacina-Łanowski, W. Stankowski, A. Świerczek, Oświęcim 2017.

Nieć M., Filozofia polityki Victora Frankla w cieniu Holocaustu. Refleksje politologa, „Roczniki Nauk Społecznych" 2014, nr 3.

Sartre J.P., Problem bytu i nicości. Egzystencjalizm jest humanizmem, Warszawa 2001.

Scheler M., Istota osoby moralnej, [w:] Filozofia i socjologia XX w., cz. 2, Warszawa 1965.

Sloan J.P., Jerzy Kosiński. Biografia, Warszawa 1997.

Szahaj A., Teoria krytyczna szkoły frankfurckiej. Wprowadzenie, Warszawa 2008.

Teologia i filozofia żydowska wobec Holocaustu, red. P. Śpiewak, Gdańsk 2013.

${ }^{88}$ Frankl nawiązał do Schopenhauera i hinduskiej religii, dla której cierpienie jest równoznaczne z życiem doczesnym.

${ }^{89}$ V.E. Frankl, Homo patiens..., s. 81. 
Teorie i metody w naukach politycznych, red. D. Marsch, G. Stoker, Kraków 2006.

Victor Frankl Institut. The Official Website of the Victor Frankl Institut Vienna, www.viktorfrankl. org/e/lifeandwork.

Wojtyła K., Pieśń o Bogu ukrytym: poezje, Warszawa 1998.

\section{IDEA OF „THE UNCONSCIOUS GOD”- AFTER THE HOLOCAUST CONSIDER OF VICTOR FRANKL}

\section{Summary}

The article presents an idea of „the unconscious God” of V. Frankl (1905-1997), a psychoanalyst and a founder of so called ,third Vienesse school”. Frankl, a prisoner of Auschwitz (no. 119 104) and Dachau, analyzes a modern World as a doctor (psychiatrist) and a philosopher. The author shows how experience of concentration camps (1942-1945) influences his moral philosophy. In his, a victim of the Holocaust, opinion, modern society is endlessly in crisis, which appears to begin in modern Europe. Frankl, in a book „The Unconscious God”, gives an option to modern human and also discusses on the one hand a pessimistic vision of ,death of God" in Auschwitz (M. Buber, H. Jonas), and on the other optimistic vision of neopsychoanalysis (E. Fromm).

Keywords: psychoanalyst, modern society, Auschwitz, moral philosophy, the Church of Catholic, human condition.

Mateusz Nieć

mateusz.niec@z.wroc.pl 